\title{
Postplacental IUCD CuT380A: Acceptability, Effectivity and Side Effects
}

\section{AKDR Cu T380A Pascaplasenta: Penerimaan, Efektivitas dan Efek Samping}

\author{
Herbert Situmorang, Ivanna T Setijanto, Biran Affandi \\ Department of Obstetrics and Gynecology \\ Faculty of Medicine Universitas Indonesia/ \\ Dr. Cipto Mangunkusumo Hospital \\ Jakarta
}

\begin{abstract}
Objective: To evaluate the acceptability, effectivity and side effects of Postplacental IUCD after vaginal delivery at Dr. Cipto Mangunkusumo Hospital (RSCM) after 6 month of insertion.

Methods: A prospective study was conducted at RSCM Jakarta during the period of August to October 2012. Postplacental IUCD was inserted into the subjects' uterus until it reached the fundus. Follow up was done at 40-42 days and 6 months after delivery.

Results: A total of 234 women were recruited in this study, with $19.2 \%$ loss of follow up. No significant difference on subjects' characteristics who came and loss of follow up in this study. Expulsion was experienced by $5.1 \%$ subjects (total expulsion $4.1 \%$ and partial $1 \%$ ) at the first visit on $40-42$ days and $7.5 \%$ subjects (total expulsion $0.6 \%$ and partial $6.9 \%$ ) at the second visit, after 6 months. 9.3\% subjects had the IUCD removed at the first and second visit. Among all of the subjects who had the IUCD removed by request or had the expulsion, $61 \%$ were willing to do reinsertion. The effectivity of IUCD was $100 \%$, with $68.9 \%$ subjects was still breastfeeding. The side effects were vaginal discharge (23\%), dysmenorrhea (4-21\%), and spotting (2-10\%).

Conclusion: The acceptability and effectivity of postplacental IUCD after 6 months were $86.8 \%$ and $100 \%$. Cummulative expulsion rate were $12.6 \%$, and the most common side effects were vaginal discharge, dysmenorea, and spotting.

[Indones J Obstet Gynecol 2017; 5-4: 213-218]

Keywords: acceptability, effectivity, expulsion rate, IUD, postplacenta
\end{abstract}

\begin{abstract}
Abstrak
Tujuan: Mengevaluasi penerimaan, efektivitas dan efek samping AKDR pascaplasenta pada persalinan pervaginam di RSCM selama periode 6 bulan setelah pemakaian.

Metode: Penelitian observasional kohort prospektif dilakukan di RSCM Jakarta pada Agustus-Oktober 2012. Alat kontrasepsi dalam rahim (AKDR) pascaplasenta dipasang pada uterus hingga mencapai fundus uteri. Penilaian dilakukan pada kunjungan 40-42 hari pascasalin dan 6 bulan kemudian

Hasil: Jumlah total subjek 234 orang, dengan 19,2\% loss of follow up. Tidak terdapat perbedaan bermakna antara subjek yang datang dan loss of follow up. Ekspulsi terjadi pada 5,1\% subjek (ekspulsi total 4,1\% dan parsial 1\%) pada 40-42 hari pascasalin dan 7,5\% subjek (ekspulsi total 0,6\% and parsial 6,9\%) setelah 6 bulan pemasangan. Total 9,3\% subjek melepas AKDR pada kunjungan pertama dan kedua. Dari seluruh subjek yang melepas AKDR atas permintaan atau mengalami ekspulsi, $61 \%$ di antaranya bersedia dipasang ulang. Efektivitas AKDR 100\%, dengan 68,9\% subjek masih menyusui. Efek samping antara lain keputihan (23\%), dismenorea (4-21\%), dan perdarahan bercak (2-10\%).
\end{abstract}

Kesimpulan: Penerimaan dan efektivitas AKDR pascaplasenta setelah 6 bulan pemakaian adalah $86,8 \%$ dan $100 \%$. Ekspulsi kumulatif sebesar 12,6\%, dan efek samping tersering adalah keputihan, dismenorea dan perdarahan bercak

[Maj Obstet Ginekol Indones 2017; 5-4: 213-218]

Kata kunci: AKDR, efektivitas, ekspulsi, pascaplasenta, penerimaan

Correspondence: Herbert Situmorang, drherbert@gmail.com

\section{INTRODUCTION}

During the postpartum period, the majority of women (92-98\%) do not want to get pregnant in 2 months after delivery, based on current world demographics and health surveys. During the postpartum period, $66.5 \%$ wants to use contraception in the first year, yet $40 \%$ of them does not get contraception care due to many reasons. ${ }^{1-3}$ Postpartum contraception is the righ test period to start contraception use. ${ }^{2,3}$

Lactational Amenorrhea Method (LAM) as a postpartum contraception, has resulted $98 \%$ in effectiveness if the woman has not have menstruation, exclusive breastfeeding, and the infant age is less than 6 months. ${ }^{2-5}$ If LAM requirements are not fulfilled, other effective contraceptive methods are needed. ${ }^{4}$

Progestin hormonal contraception method can be used as a postpartum contraception. However, progestin is a short-term contraception. Implant is a long-term contraception, which is effective for 3-5 years. ${ }^{2,6}$ 
IUCD can be applied during the postpartum period, including post-placenta (in 10 minutes after placenta delivery) ${ }^{3,5,7-13}$, immediate/delayed (in 48 hours until before 6 weeks postpartum) ${ }^{14}$ and IUCD after puerperium or interval. ${ }^{11-12,15,16}$ The use of post-placental IUCD is relatively more comfortable, safe, efficient with lower infection incidence ${ }^{17,18}$, bleeding problem, perforation ${ }^{15}$, and expulsion $^{9,10,17,19}$ than immediate or delayed postpartum insertion. ${ }^{16}$

Post-placenta IUCD has been introduced since 40 years ago in Indonesia. ${ }^{20}$ The acceptability of post-placental IUCD Multiload Copper 250 (ML$\mathrm{Cu} 250$ ), for 3 months of observation, reaches 91.1\%. ${ }^{21}$ The effectiveness of post-placental IUCD reaches $2.4 \%$ delivery in 1 year. ${ }^{10}$ Factors affecting acceptability are expulsion rate and side effects such as bleeding and pain.8,11,12 The average of post-placental IUCD expulsion rate ranges cumulatively from $11 \%$ through $15 \%$ in many countries. In Indonesia, post-placental IUCD expulsion rate is estimated ranging from 6\% through $10 \% .{ }^{14}$ Expulsion rate can be reduced by post-placental insertion, done by experienced installer, and placed precisely in fundus uteri. ${ }^{22}$

A previous study in RSCM had been done by Badan Kependudukan dan Keluarga Berencana Nasional (BKKBN). The research interviewed subjects who were inserted IUCD 6 months after delivery. The acceptability was $68 \%$ and $26 \%$ of the subject removed the IUCD outside RSCM. The most common side effects were lower abdominal pain $(40 \%)$, and the total expulsion rate was 6 percent. $^{23}$

A study about the acceptability, effectiveness, and side effects of post-placental IUCD $\mathrm{Cu}$ T380A at RSCM with direct clinical evaluation is an operational study which can be used to support optimal postpartum care in Indonesia generally and to support contraception care in RSCM. Therefore, studies which can show these data are required to be conducted.

\section{METHODS}

A prospective study was conducted in the Obstetrics and Gynecology Department, FMUIRSCM Jakarta during the period of August to October 2012. Patients who met the study criteria were included in the study after signing informed consent. The study protocol had been approved by the RSCM ethics commission. Inclusion criteria: subjects who were at term pregnancy and scheduled to do vaginal delivery in RSCM, both referral and patient from policlinic and ward. Subject and partner were willing to participate in the study and chose IUCD as post-placenta contraception method.

Exclusion criteria included presence of uterus anatomic abnormalities, history of menometrorrhagia or dysmenorrhea, history of blood clotting disorders, history of fever or other clinical signs and symptoms that were related to intrauterine or intrapartum infection, history of previous ectopic pregnancy, rupture of the fetal membrane more than 24 hours before hospital admission, delivery which occurred for 24 hours without significant progress and postpartum bleeding.

Subjects who were included in the study would be inserted with IUCD Cu T380A, immediately 10 minutes after placenta were delivered. IUCD was inserted in uterine cavity until it reached fundus with the help of the provider's hand. Providers were Obstetrics and Gynecology FMUI-RSCM residents who were well-trained to do postplacenta IUCD insertion. After insertion, subjects were informed to come in 40-42 days postpartum and 6 months postpartum. Subjects were given a special card to assess bleeding, and to write down address and contact number.

On the next visit, every subject was asked whether there was IUCD which spontaneously expelled, whether she still breastfed, and whether she had gotten her menstrual period. If the patient had got menstruation, patient was asked whether there was any complaint, bleeding, and pain. Patient was also asked whether there was a pregnancy and other complaints were noted. Subject was also asked about satisfaction in using IUCD for 6 months.

Examination using speculum was performed on each subject to assess detached thread from ostium and any other pathology feature in the examination. If IUCD threads were not seen in ostium, the doctor would perform transvaginal USG to ensure the existence of IUCD.

\section{RESULTS}

The total number of subjects participating in this study was 234. All subjects were inserted with post-placental IUCD $\mathrm{Cu}$ T380A after vaginal 
delivery both spontaneously and equipped in RSCM. All subjects were asked and reminded by phone to come in the first re-visit, which was 40-42 days postpartum and 6 weeks postpartum. Subjects who did not come in the first re-visit were re-contacted to come to second re-visit. However, 30 subjects did not come to first and second revisit, 15 subjects did not come to second re-visit, $19.2 \%$ subjects were loss of follow up. There was no statistically significant difference in the characte-ristics of the subject who came and were loss of follow up.
In patients who removed their IUCD outside RSCM, the most common reasons were presence of the thread which was palpable in the genitalia and vaginal bleeding. IUCD thread could not be seen in $32.6 \%$ subjects in the first re-visit and 25\% subjects in the second re-visit. Of all the subjects who were both expulsion and removed by request, $8.5 \%$ was re-explained and agreed to re-install the IUCD.

There was no pregnancy in any subject for 6 months use of IUCD, $68.9 \%$ subjects still breastfed

Table 1. Subjects' Characteristic based on Postplacental IUCD Acceptability

\begin{tabular}{|c|c|c|c|}
\hline Characteristic & $\begin{array}{l}\text { Collectable subjects } \\
\qquad(\mathrm{n}=189)\end{array}$ & $\begin{array}{c}\text { Loss of follow up } \\
(n=45)\end{array}$ & $\mathbf{p}$ \\
\hline \multicolumn{4}{|l|}{ Age } \\
\hline Mean (IK 95\%) & $27.21(26.36-28.06)$ & $27.11(25.25-28.97)$ & \multirow{2}{*}{$0.938^{\mathrm{a}}$} \\
\hline Median (IQR) & $27.00(22.00-31.00)$ & $27.00(23.00-31.50)$ & \\
\hline \multicolumn{4}{|l|}{ Age group } \\
\hline$\leq 18$ years, $\mathrm{n}(\%)$ & $11(5.8)$ & $3(6.7)$ & \multirow{5}{*}{$0.982^{\mathrm{b}}$} \\
\hline 19-25 years, n (\%) & $67(35.4)$ & $16(35.6)$ & \\
\hline 26-30 years, n (\%) & $56(29.6)$ & $14(31.1)$ & \\
\hline 31-35 years, n (\%) & $32(16.9)$ & $6(13.3)$ & \\
\hline >35 years, $\mathrm{n}(\%)$ & $23(12.2)$ & $6(13.3)$ & \\
\hline \multicolumn{4}{|l|}{ Education } \\
\hline Non educated, n (\%) & $1(0.5)$ & $1(2.2)$ & \multirow{4}{*}{$0.982^{c}$} \\
\hline Elementary school, n (\%) & $12(6.3)$ & $4(8.9)$ & \\
\hline Junior high school, n (\%) & $48(25.4)$ & $13(28.9)$ & \\
\hline Senior high school, n (\%) & $128(67.7)$ & $27(60.0)$ & \\
\hline \multicolumn{4}{|l|}{ Obstetrical status } \\
\hline Primipara, n (\%) & 97 (51.3) & $24(53.3)$ & \multirow{3}{*}{$1.000^{\mathrm{c}}$} \\
\hline Multipara, n (\%) & $88(46.6)$ & $21(46.7)$ & \\
\hline Grande Multipara, n (\%) & $4(2.1)$ & $0(0.0)$ & \\
\hline
\end{tabular}

Note:

a Mann-Whitney statistical analysis

${ }^{b}$ Chi-square statistical analysis

cKolmogorov-Smirnov statistical analysis

Expulsions occured in $5.1 \%$ subjects (total expulsion rate was $4.1 \%$ and partial expulsion rate was $1 \%$ ) in the $40-42$ day visit and $7.5 \%$ subjects (total expulsion rate was $0.6 \%$ and partial expulsion rate was 6.9\%) after 6 months. During the first and second re-visit, $9.3 \%$ patients removed IUCD, $2 \%$ subjects requested to remove IUCD because they complained pain during sexual intercourse, leukorrhea, and bleeding. yet $20.1 \%$ subjects had not got menstruation. The most common side effects were leukorrhea $(23 \%)$, menstrual pain (4-21\%), and spotting (2-10\%). Most of the subjects (45.3-60.1\%) had no complaint. Although some patients developed side effects, the majority of the patients were satisfied using post-placenta IUCD $\mathrm{Cu}$ T380A. Most of the patients who removed IUCD outside RSCM were not satisfied using IUCD. 
Table 2. Six Months Lifetime Table

\begin{tabular}{lcc}
\hline \hline Variable & N & \% \\
\hline Pregnancy & 0 & 0 \\
Partial expulsion & 14 & 7.9 \\
Total expulsion & 9 & 4.7 \\
Acceptability & 164 & 86.8 \\
Loss of follow up & 45 & 19.2 \\
Total subjects recruited & 234 & - \\
Subjects included in this study & 189 & - \\
\hline \hline
\end{tabular}

\section{DISCUSSION}

As a contraceptive method used during the postpartum period, IUCD has many advantages. Besides, it does not affect breast milk, IUCD is a reversible contraception method and does not need subject compliance to come in the certain time, not depending on the time having sexual intercourse and minimal pain when it was inserted post- partum. Ideal insertion time is 10 minutes after placenta is delivered or in 48 hours after delivery, with higher expulsion rate in the insertion after 48 hours. ${ }^{24}$

This study was an operational study which studied about post-placenta IUCD Cu T380A which was performed in RSCM. Evaluation was done in 40-42 days and 6 months after insertion. Previous study about post-placenta IUCD, performed follow up in post-puerperial period (40-42 days), 6 months, and 1 year after delivery. ${ }^{8-12,24,25}$

The acceptability of post-placenta IUCD $\mathrm{Cu} T$ $380 \mathrm{~A}$ until the end of the study was $86.9 \%$. Acceptability of post-placental IUCD in the previous study using IUCD ML Cu 250 was $91.1 \%{ }^{21}$, while in the study which was conducted in Turkey compared post-placental insertion, delayed and interval, acceptability of post-placenta IUCD reached. $72.0 \%^{26}$ Lower acceptability compared with previous study which was done follow up for 3 months postpartum was affected by low subject compliance, lack of information which was given in patient education. $7.4 \%$ subjects removed IUCD outside RSCM, majority of which due to detached thread complaint (3.2\%).

Effectiveness of IUCD for 6 months in this study was $100 \%$. All subjects who used IUCD until the end of the study, there was no one getting pregnant. That number was also affected by breastfeeding activity until 6 months postpartum in
$68.9 \%$ subjects. Effectiveness of the MAL was $98 \% .^{2-5}$ Failure rate or pregnancy incidence was less than $1 \%$ in the first year use of IUCD. In the long-term study sponsored by WHO, average of the failure rate per year was $0.4 \%$ or lower, and cumulative failure rate in 12 years was $2.2 \%$, which was comparable to tube sterilization. ${ }^{19}$ In the previous studies, effectiveness after one year use of IUCD was assessed. Further study to assess long-term effectiveness of post-placental IUCD needs to be done. . $^{-12,17,24}$

Expulsion assessment in this study was obtained 197 from the first re-visit (40-42 days postpartum), $90.4 \%$ of subjects IUCD was located fully inside uterine cavity, most of IUCD shifted to cervix in $1 \%$ and $4.1 \%$ of cases encountered total expulsion. In visit of 6 months IUCD use, $0.6 \%$ of cases encountered total expulsion and $6.9 \%$ of cases encountered partial expulsion, so that cumulative expulsion rate was $12.6 \%$. Based on the previous study, cumulative expulsion rate after 6 months insertion was, in China $13.3 \%{ }^{12}$, in Mali $15 \%{ }^{9}$, and in Turkey $33.4 \%{ }^{10}$

A study conducted in India and Turkey had lower cumulative expulsion rate which were $10.68 \%{ }^{24}$ and $7 \% .^{8}$ The most common factors affecting expulsion risks included the experience and expertise of health care provider who performed insertion and insertion technique. ${ }^{10} \mathrm{In}$ this study, all installers were trained before the study was conducted so that installer ability was considered the same, yet installer experience became factor that needed to consider.

Evaluation of IUCD distance from fundus uteri could be assessed by trans-vaginal USG to determine expulsion objectively. In the study conducted in Brazil, trans-vaginal USG was performed to assess IUCD position in its exact place if IUCD distance was not more than $3 \mathrm{~mm}$ from fundus. ${ }^{27}$ In the next study, it could be evaluated further about exact distance IUCD, by trans-vaginal USG evaluation in each re-visit.

In this study, there was no perforation, one IUCD malposition was occured in subjects with dyspareunia and reinserted after that IUCD was removed. Numerous multicenter studies found no perforation or infection in post-placental IUCD user. ${ }^{24}$ In patients whose intrauterine IUCDs were not detected on USG, and from anamnesis the patient did not feel any detached IUCD from genitalia, perforation should be removed by 
abdominal $\mathrm{x}$ ray examination, which was seldomly performed in this study. ${ }^{24}$

Infection in puerperal period did not happen in this study. Welkovic et al, stated that $3.4 \%$ of IUCD users complained puerperal infection but it was not statistically significant different with subjects not using IUCD. ${ }^{28}$ Non-itchy and non-stinky leukorrhea as unexpected complaints by the authors was $23.1 \%$. $90 \%$ of which still satisfied using IUCD although the complaints existed.

Leukorrhea were not found in IUCD $\mathrm{Cu}$ T380A users. $^{25}$ Eroglu et al stated that leukorrhea complaints which were confirmed by the existence of pathogen were only $1.6 \%$ in 6 months postpartum and there was no infection in 8 weeks postpartum in postpartum IUCD insertion. ${ }^{15}$ The weakness of this study was no analysis for leukorrhea as complaint, therefore further studies to analyze leukorrhea complaint objectively by finding the pathogens in subject with leukorrhea complaints are needed to be done.

Welkovic found menorrhagia in IUCD users. ${ }^{28}$ In this study, subjective menorrhagia complaint was $5 \%$ and objectively was $2.8 \%$ that in the subject's note, bleeding was no more than 5 times changing bandages per day. Thirty three percent of subjects with menorrhagia did not satisfy because of the bleeding. They requested to remove IUCD. Welkovic et al, stated that bleeding and infection after postpartum IUCD insertion were not associated with a lot of bleeding incidence in menstrual cycle. ${ }^{28}$

In the cumulative side effect assessments, bleeding other than menstruation was spotting subjectively in $15.3 \%$ of the subjects and objectively in $4.8 \%$ of the subjects. It was because subject did not note properly in the same day. However, $75 \%$ of the subjects satisfied using IUCD although there were spotting complaints. All inert IUCD and copper release increased bleeding volume in menstruation when using IUCD, the most possible causes were increase of fibrinolysis activity and local effect on prostacyclin/ thromboxane balance in endometrium. New generation IUCD such as $\mathrm{Cu}$ T380 and Multiload were reported to cause $50-75 \%$ increase in menstrual blood volume. ${ }^{29}$

\section{CONCLUSION}

The acceptability and effectiveness for 6 months were $86.8 \%$ and $100 \%$. Expulsion rate side effect for 6 months was cumulatively $12.6 \%$. Other side effects were leukorrhea, menstrual pain, and spotting.

\section{REFERENCES}

1. Ross, John A and Winfrey, William L. Contraceptive Use, Intention to Use and Unmet Need During the Extended Postpartum Period. Int Fam Plan Perspec, 2001; 27(1): 20-7.

2. Evans A. Postpartum Contraception. Women's Health Medicine. The Medicine Publishing Company Ltd. 2005; 25: 23-6.

3. Stephenson P and McDonald P. Family Planning for Postpartum Women: Siezing A Missed Opportunity. Global Health Technical Briefs. USAID. 2005: 1-2.

4. Saifuddin AB. Metode Kontrasepsi. Buku Panduan Praktis Pelayanan Kontrasepsi. Biran Affandi, Moh. Baharuddin, Soekaemi Soekir, Ed 2. Jakarta: Yayasan Bina Pustaka Sarwono Prawirohardjo, 2010: p. MK-01-88.

5. Farrell B and Huber D. Module 13: Postpartum and Postabortion Contraception. Comprehensive Reproductive Health and Family Planning, Training Curriculum. Pathfinder Int; 1998: 6.

6. Centers for Disease Control and Prevention. Update to CDC's US Medical Eligibility Criteria for Contraceptive Use, 2010: Revised Recomendations for the Use of Contraceptive Methods during the Postpartum Period. MMWR 2011; 60: 878-83.

7. Ozalp SS. Copper containing, framed intrauterine devices for contraception: RHL commentary (last revised: 15 December 2006). The WHO Reproductive Health Library; Geneva: World Health Organization.

8. Celen S, Moroy P, Sucak A, et al. Clinical Outcomes of Early Postplacental Insertion of Intrauterine Contraceptive Devices. Contracep 2004; 69(4): 279-82.

9. Morrison C, et al. Clinical Outcomes of Two Early Postpartum IUD Insertion Programs in Africa. Contracep 1996; 53(1): 17-21.

10. Eroglu K, Akkuzu G, Vural G, et al. Comparison of Efficacy and Complications of IUD Insertion in Immediate Postplacental/early Postpartum Period with Interval Period: 1 Year Follow-up. Contracep 2006; 74(5): 376-81.

11. Kapp N and Curtis KM. Intrauterine Device Insertion During the Postpartum Period: A Systematic Review. Contracep 2009; 80(4): 327-36.

12. Xu J-X, Rivera R, Dunson TB, et al. A Comparative Study of Two Techniques Used in Immediate Postplacental Contracep 1996; 54(1): 33-8.

13. Salem HT, Kamel MA, Mohamed SA, et al. Acceptability of Postpartum IUD (PPIUD). Dept OB/GYN, Faculty of Medicine, Assiut University, Assiut, Egypt 2004; 6: 21. 
14. Saifuddin AB. AKDR Post-Plasenta. Buku Panduan Praktis Pelayanan Kontrasepsi. Biran Affandi, Moh. Baharuddin, Soekaemi Soekir. Ed 2. Jakarta: Yayasan Bina Pustaka Sarwono Prawirohardjo; 2010: p. MK-78.

15. Blanchard H and McKaig C. ACCESS-FP. The IUD: A Contraceptive Option for Postpartum and Postabortion Women. IUD Toolkit. 8 January 2006. <http://www.k4health.org/ toolkits/iud/iud-contraceptive-option-postpartum-andpostabortion-women>

16. O'Hanley K and Huber DH. Postpartum IUDS: Keys for Success. Contracep 1992; 45(4): 351-61.

17. Grimes D, et al. Immediate Post-partum Insertion of Intrauterine Devices. Cochrane Database Syst Rev 2003; (1): CD003036.

18. Muller AL, Ramos JGL, Martins-costa SH, et al. Transvaginal Ultrasonographic Assessment of The Expulsion Rate of Intrauterine Devices Inserted in The Immediate Postpartum Period: A Pilot Study. Contracep 2005; 72(3): 192-5.

19. Bluestone J, Chase R and Lu ER. Introduction to Intrauterine Contraception Devices. IUD Guidelines for Family Planning Service Programs. Baltimore: JHPIEGO; 2010: 1-12.

20. Soetopo. Pemasangan Dini IUD. Jakarta: Program Studi Obstetri dan Ginekologi, Program Pendidikan Dokter Spesialis-I, Fakultas Kedokteran Universitas Indonesia; 1972.

21. Sitompul E. Penerimaan dan Daya guna AKDR MLCu-250 Pascaplasenta, Hasil Observasi Jangka Pendek. Jakarta: Program Studi Obstetri dan Ginekologi, Fakultas Kedokteran Universitas Indonesia; 1994.
22. The ACQUIRE Project. The Postpartum Intrauterine Device: A Training Course for Service Providers. Participant Handbook. New York: Engender Health. 2008; (6)9: 51-3.

23. Anggraeni M, Asih L dan Pujihastuty R. Operasional Research IUD Post Plasenta di Rumah Sakit Cipto Mangunkusumo (RSCM). Jakarta: Puslitbang KB dan Kesehatan Reproduksi BKKBN, 2010: 27.

24. Shukla M, Qureshi S and Chandrawati. Post-placental Intrauterine Device Insertion - A Five Year Experience at Tertiary Care Centre in North India. Ind J Med Res 2012; 136: 432-5.

25. Reinprayoon D, Gilmore C, Farr G, et al. Twelve-months Comparative Multicenter Study of The TCu380A and ML 250 Intrauterine Devices in Bangkok, Thailand. Contracep 1998; 58(4): 201-6.

26. Hasson HM, Copper IUDs. J Reprod Med 1978, 20:139-54.

27. Petta CA, Faundes D, Pimentel E et al. The Use of Vaginal Ultrasound to Identify Copper T IUs at High Risk of Expulsion. Contracep 1996; 54: 287-9.

28. Welkovic S. Post-partum Bleeding and Infection after Postplacental IUD Insertion. Contracep 2001; 63(3): 155-8.

29. Odlind V. Modern Intra-uterine Devices. Bailliere's Clinical Obstetrics and Gynaecology. Bailliere Tindall; 1996. <http://www.ncbi.nlm.nih.gov/pubmed/8736722> 